\title{
PAI Learning Management in Improving Student Learning Outcomes
}

\author{
Apriani $^{1 *)}$, Happy Fitria ${ }^{2}$, Yenny Puspita ${ }^{2}$ \\ ${ }^{1}$ SMA Negeri 1 Buay Sandang Aji, South of Sumatera, Indonesia \\ ${ }^{2}$ Universitas PGRI Palembang, Indonesia \\ *Corresponding author. Email: aprianiimam@gmail.com
}

\begin{abstract}
This study aims at implementing and managing Islamic Education learning management in improving student learning outcomes at SMA Negeri 1 Buay Sandang Aji, South OKU Regency. The research design used a qualitative research design. The data collection tools used were interviews, observation, and documentation. The data analysis technique used qualitative analysis techniques including data, data reduction, data presentation, and data collection and verification. The results of the analysis in this study show that several things that have been made to improve the quality of Islamic education learning at SMA Negeri 1 Buay Sandang Aji cannot be separated from all the roles of teachers, management of Islamic learning at SMA Negeri 1 Buay Sandang Aji has been running properly.
\end{abstract}

Keywords: Learning Management, Learning Outcomes, PAI

\section{INTRODUCTION}

Islamic religious education as a subject in schools has an important role in instilling a sense of piety to Allah SWT. Therefore, learning Islamic religious education in schools is not only provided in the form of materials but also conducts practices such as prayer, recitation, and other things related to deeds. The performance of schools in enhancing learning quality is a collaborative effort between teachers and school principals [1].

Believed that the world of Islamic education in Indonesia is currently facing various tough challenges. Among these challenges are globalization in the fields of culture, ethics and morals, as a result of technological advances (transportation and information), and low levels of social-capital, low quality of education in Indonesia, and national macro problems, which involve multidimensional crises in both fields. economics, politics, morals, culture and so on [2].

Thus, from the various challenges mentioned above, the world of education is often criticized by many people due to the behavior of students and graduates who show less commendable attitudes. Students are involved in brawls, theft, crime, immorality, while the unemployed are generally academic graduates [3].

While other opinions say that the failure of Islamic education is due to its educational practice only paying attention to the cognitive aspects of the growth of awareness of religious values (internalization), and ignoring affective, conative-volitive aspects, namely the willingness and determination to do good [2].

Various ideas and actions have been taken to solve the various problems and failures above, such as the reactualization of madrasas, leading Islamic schools, and Islamic education with an integrated system or the application of integrated Islamic education management. Even character education is proclaimed in all educational institutions in Indonesia. The implementation of education (schools) with an integrated system has been running optimally in recent years and has attracted the attention of the public, where this integrated system requires additional study time, so it is commonly known today as a model school or full day school program, namely a full day school.

Stated the definition of Islamic education management as the science of managing educational resources (human) and cost resources, methods, environment, technology, and others through the planning process, organizing, implementing, monitoring to achieve predetermined educational goals effectively and efficiently [4]. So integrated Islamic education management is an activity of structuring, managing, planning, organizing, implementing various existing resources so as to achieve educational goals.

Management of Islamic education is carried out with the integration of several elements, namely: first, integrating the mode of education in families and communities in the school environment [5]. Second, integrating the cognitive, affective and psychomotor 
domains. Third, integrating general education (National) with Islamic education. Fourth, integrating the classical learning process with the surrounding environment, including mosques, laboratories, and the like. Fifth, integrating the process of mastery of life sciences with Tsaqafah Islamiyah and the formation of Syakhsyiyah Islamiyah.

Claimed learning management can affect the level of quality of learning in the classroom because learning management will actually manage the atmosphere of the class to be the best possible so that students will be comfortable and happy during the Teaching and Learning Process (PBM) so that goals can be achieved optimally. In order for the quality of student learning to run well, the implementation of basic management functions is needed by teachers to achieve optimal results and basic competencies that are expected to be achieved properly and satisfactorily [6]. Teachers must carry out a more creative learning process for students in order to develop their [7]. The achievements and prestige of the institution are highly dependent on the quality of learning, facilities and infrastructure, supporting facilities, teachers and students, and learning outcomes [8].

Efforts to improve learning outcomes in learning also SMA Negeri 1 Buay Sandang Aji, South OKU Regency, especially in learning Islamic Religious Education (PAI) has at least implemented this learning management with the aim of achieving optimal results, such as in the Teaching and Learning Process (PBM) activities that have implemented the method. -methods suitable for the learning material at that time. Teachers are declared successful in organizing learning if they are able to change the behavior of most students towards better mastery of competencies [9]. The classroom atmosphere is not quiet, and the students' communication between teachers looks harmonious both inside and outside the classroom. However, during the lesson there are students who talk to their friends by themselves even though the teacher is explaining the material in front of the class.

Based on the observations of researchers at SMA Negeri 1 Buay Sandang Aji, South OKU Regency, the learning process of Islamic religious education at SMA Negeri 1 Buay Sandang Aji in South OKU Regency was good enough, it was proven that teachers got students accustomed to reading the Al-Quran before starting learning and invited students to carry out prayer worship practices. In addition, in the process of implementing Islamic religious education learning at SMA Negeri 1 Buay Sandang Aji, South OKU Regency, the teacher also used several methods, media, and evaluations adapted to the subject matter to facilitate the teaching and learning process. Besides that, the school also held regular recitation every month. This was done only to motivate students to be active in carrying out worship, especially the five daily prayers.
One of the goals of SMA Negeri 1 Buay Sandang Aji, South OKU Regency, is to prepare students to obey the practice of worship, but in reality, in the field of practicing the implementation of worship, especially the practice of the fardlu prayer had obstacles, namely low enthusiasm for carrying out the Fardlu prayer. The Islamic religious education that had been given to students does not make some students want to practice worship practices such as prayer, it was evident that there were still some students who did not want to pray or postponed prayer times. In addition, the environmental factor around the school was less religious, which made students less enthusiastic in carrying out the Fardlu prayer. Thus, this could be used as the reason why the author wanted to do research at SMA Negeri 1 Buay Sandang Aji, South OKU Regency.

Based on the description above, the writer wished to conduct a research on PAI Learning Management in Improving Student Learning Outcomes at SMA Negeri 1 Buay Sandang Aji, South OKU Regency.

\section{METHODS}

Methodology is a determining factor for the merits of writing scientific papers [10]. The research method used in this research was a qualitative method. Data collection techniques in this study used observation techniques, interviews and documentation studies. The data analysis techniques used in this study included data reduction, data presentation and conclusion drawing. The data that had been obtained would be processed using qualitative research, then conduct a domain analysis to obtain a general and comprehensive picture of the object of research through the process of data reduction, display and verification [11].

To ensure certainty that this study was objective, the researcher in this case carried out a careful examination together with the supervisor of the certainty of the origin of the data, the logic of drawing conclusions from the data and the degree of accuracy as well as a review of the researcher's activities regarding the validity of the data.

\section{RESULTS AND DISCUSSION}

The application of PAI Learning Management at SMA Negeri 1 Buay Sandang Aji, South OKU Regency in 2019/2020 obtained the following results:

\section{1) Planning PAI Lessons at SMA Negeri 1 Buay Sandang Aji}

The learning process at SMA Negeri 1 Buay Sandang Aji was carried out by realizing the designs that had been compiled in the syllabus, annual programs, learning plans, and academic calendars. Learning planning carried out by a teacher would determine the success of the learning he led. This was 
based on the fact that making a lesson plan that includes an annual program, semester program, preparation of a syllabus and a good or more detailed learning plan would make it easier for teachers to deliver learning materials. Organizing students in the classroom and implementing the evaluation of both learning processes and learning outcomes.

The teacher would have a learning reference according to the ability of himself and students who would become the subject and object of learning in class and outside the classroom, the better and more detailed. Learning planning prepared by the teacher, it would be more helpful and easier for teachers in implementing learning. In preparing the lesson plan for each subject, the steps that must be considered by a teacher were: 1) Describing or determining basic competencies; 2) Choosing teaching materials; 3) Planning learning activities; 4) Determine the media and learning tools and 5) Compile evaluation.

There were things that need to be considered by a teacher in relation to the ability to plan lessons, namely: 1) Mastering the syllabus; 2) Compiling subject matter analysis (AMP); 3) Compiling a semester program; 4) Develop a lesson plan. Learning planning prepared by a teacher can be used as a guide that really helps the teacher, not only in order to present learning material but can also be used as material for evaluating the learning process carried out at that time, so that the implementation of the next learning can run better and optimally in achieving learning objectives.

\section{2) Organizing Islamic Education Learning at SMA Negeri 1 Buay Sandang Aji}

In organizing teaching learning at SMP Negeri 2 Manyaran is able to create a conducive classroom atmosphere. This can be seen enthusiastically by students in following subjects and feeling comfortable in class because the class conditions are clean, comfortable and pleasant and there are mottos, writings that provide motivation to study actively. And there is a good relationship between educators and students because educators at SMA Negeri 1 Buay Sandang Aji are able to portray themselves as facilitator, manager, motivators, and evaluator.

\section{3) Implementation of Islamic Education in SMA Negeri 1 Buay Sandang Aji}

The implementation of learning is closely related to the role of the teacher in classroom learning, which will determine whether the learning objectives are achieved or not. In the implementation of this learning includes organizing learning and the leadership of a teacher in the learning process in the classroom. Organizing learning carried out by PAI teachers includes the division of tasks to students about things that must be done during the learning process and the goals that would and must be achieved through this learning.

In the learning process the teacher as a leader played a role in influencing or motivating students to want to do the work expected, so that the teacher's work in teaching became smooth, students easily fluent and master the subject matter so that learning objectives we achieved. Teachers should always try to strengthen students' motivation in learning. This could be achieved through engaging lesson presentations and pleasant personal relationships both in classroom and outside learning activities.

Class management is carried out according to the different needs and backgrounds of students, it's just that the arrangement of the tables and chairs still uses a conventional pattern where the teacher is the center of the learning process and students are the subject of education. Class management is an effort made by the person in charge of teaching and learning activities or those who help with the intention of achieving optimal conditions, so that learning activities can be carried out as expected. In teaching and learning, the class is a place that has a characteristic used for learning. Learning requires concentration therefore it is necessary to create a classroom atmosphere that can support effective learning activities. The purpose of class management is so that every child in the class can work in an orderly manner so that teaching objectives are achieved effectively and efficiently. The teacher plays a very important role in class management, if the teacher is able to manage the class well, it is not difficult for the teacher to achieve the goals that have been formulated.

The learning strategy carried out by Islamic Education teachers was in accordance with the general reference which consisted of three stages. First: the preinstructional stage (introduction). In this stage the PAI teacher had made it a habit to always pray with students before carrying out a learning process. And after that asked about the presence of students, and carried out a pre-test in the form of questions and answers, quizzes or others. Second: The instructional (core) stage. In this stage the PAI teacher conducted a series of learning activities with students in order to achieve learning objectives. The learning resources used in the Islamic Education learning process were in accordance with the learning material. For example, in learning activities at SMA Negeri 1 Buay Sandang Aji, the methods used were very varied, namely, the lecture method, the question answer method, the discussion method, the demonstration method, and the assignment method. These methods could provide students with easier comprehension in digesting lessons which could be identified in evaluation activities. The learning approach taken by SMA Negeri 1 Buay Sandang Aji in delivering the material was already good, while the media used also varies, such as buildings, plots, religious facilities, books, props, and so on. so that it could support the 
learning process. Third: The post-instructional stage (closing). In this stage the teacher provided reinforcement or conclusions about the learning that has been undertaken. Providing reinforcement or conclusions about learning material to students would be useful in providing understanding that was more related to the discussion during the learning process, this was because there were some students who could only understand a knowledge from a conclusion given by a teacher.

Actuating was the most important management function in the planning and organizing function from the entire series of management processes, which dealt with abstract aspects of the management process, whereas the actuating function emphasized activities directly related to people in the organization. Actuating was nothing but an effort to make planning a reality, through various influences and motivations so that each employee could carry out activities optimally in accordance with their roles and responsibilities.

\section{4) Evaluation of PAI Learning at SMA Negeri 1 Buay Sandang Aji}

Learning evaluation conducted by SMA Negeri 1 Buay Sandang Aji to find out the results or not. Learning that was carried out in order to achieve learning objectives was in accordance with the reference for implementing learning evaluation in the 2013 Curriculum which consists of learning evaluation and evaluation of the learning process.

The evaluation of learning outcomes carried out by PAI teachers was in accordance with the evaluation of learning outcomes contained in the 2013 Curriculum, namely class-based assessments which contain cognitive, psychomotor and affective domains. Classbased assessment is one of the components developed in the 2013 Curriculum including the subject of Islamic Religious Education (PAI). Class-based assessment on Islamic Education subjects was carried out to provide balance to the three domains (cognitive, affective, psychomotor) by using various types, forms and methods of assessment which are carried out continuously. This assessment was expected to be more useful to obtain a complete picture of the achievements and progress of the learning process and outcomes achieved by students in Islamic Education subjects.

In practice, this assessment was carried out in an integrated manner with the learning process, so that it was called class-based assessment (PBB). PBB was done by collecting students' work (portfolio), work (product), assignment (project), performance (action) and written tests (subjective, objective, and projective). PAI teachers assessed the competence and learning outcomes of students based on the level of student achievement. The role of Islamic education teachers was very important in determining the type of assessment to assess the success and failure of students. The types of assessments made by Islamic Education teachers must meet validation and reliability standards, so that the process and results achieved were in accordance with what was expected.

The thing that needs to be considered in the assessment / evaluation was the principle of continuity, that was, students continuously follow the growth, development and changes of students in learning. From the evaluation results could be used by SMA Negeri Buay Sandang Aji as a reference for improving the learning program, determining the level of mastery of students and monitoring the success of the applied learning management.

Based on several things that had been made in improving the quality of Islamic Religious Education learning at SMA Negeri 1 Buay Sandang Aji could not be separated from all the roles of teachers. Teachers must be able to position themselves and created a conducive atmosphere, because the teacher's function in schools was the second father who was responsible for the growth and development of the child's soul. In the implementation of PAI learning at SMA Negeri Buay Sandan Aji, the solutions applied were: a) Most students did not have sufficient religious background which could be overcome by the efforts made by a teacher in addition to teaching lessons in class as well as holding congregational prayers and filled with cult; b) Students who did not fully understand and understand the reading and writing of the Al-Qur'an could be overcome by increasing the practice of reading and writing repeatedly so that students would be able to read and write by themselves. Thus, the teacher must provide explanations to students slowly and clearly so that students could understand the explanation from the teacher.

Barriers to Learning Management PAI Every move of a human being is always hindered by the difficulties that confront him anytime and anywhere. Every time the educational process takes place, of course, will find obstacles to an effective learning.

The main obstacles in learning Islamic Religious Education at SMA Negeri Buay Sandang Aji were as follows: a) Most students did not have sufficient religious background Students' basic abilities about religious knowledge were very influential in the context of the PAI teaching and learning process, which directly would touch with the material to be delivered; b) Students did not quite understand and understand how to read and write Al-Qur'an; c) In general, students' abilities were different from others, especially in terms of knowing and understanding the letters of the AlQur'an. This was because the students' conditions were very diverse. 


\section{CONCLUSION}

Based on the discussion can draw the following conclusions: 1) learning planning PAI teachers made an annual program syllabus, semester program, lesson plan program and educational calendar; 2) the learning organization of Islamic Education teachers linked the material with learning resources and media so as to create a comfortable atmosphere in the classroom with the exemplary approach and akhlakul karimah owned by educators; 3) PAI teachers carried out a pre-test in the form of questions and answers, quizzes, and so on. Class management, learning strategies, learning approaches and media as well as the methods used could make it easier for students to capture the subject matter. In practice, educators must always provide motivation for students in the teaching and learning process, and 4) the learning evaluation of Islamic Education teachers carried out an assessment system in the form of a learning process and learning outcomes which includes three domains, namely: cognitive, psychomotor, and affective, this was done through pre-tests, daily tests, Mid-Semester Examination and Semester Final Examination.

\section{ACKNOWLEDGMENT}

Our deepest gratitude goes to Teachers in SMA Negeri 1 Buay Sandang Aji, Chancellor of Palembang PGRI University, Director of the Postgraduate Program of PGRI Palembang University and the Education Management Study Program of PGRI Palembang University, who have supported us in doing this extraordinary thing. This project is funded independently. We also want to thank our Education Management friends who helped us a lot in a short time frame to complete this project.

\section{REFERENCES}

[1] Khasanah, U., Kristiawan, M., \& Tobari. (2019). The Implementation of Principals' Academic Supervision in Improving Teachers' Professionalism in the State Primary Schools. International Journal of Scientific \& Technology Research, 8(8).

[2] Muhaimin. (2015). Manajemen Pendidikan: Aplikasi Dalam Penyusunan Rencana Pengembangan Sekolah/Madrasah Edisi Pertama [Education Management: Applications in School / Madrasah Development Plan Formulation First Edition]. Jakarta: Prenadamedia Group.

[3] Nata, A. (2013). Perspektif Islam Tentang Strategi Pembelajaran [Islamic Perspective About Learning Strategies]. Jakarta: Kencana.

[4] Nawawi, H. (2012). Manajemen Strategik Organisasi NonProfit Bidang Pemerintahan dengan Illustrasi di Bidang Pendidikan [Strategic Management of Governmental Non-Profit
Organizations with Illustrations in the Field of Education]. Yogyakarta: Gajah Mada University Press.

[5] Yusanto, I. (2012). Menggagas Bisnis Islam [Initiating Islamic Business]. Jakarta: Gema Isani Press.

[6] Hasbullah. (2016). Dasar-dasar Ilmu Pendidikan [Basics of Education]. Jakarta: Raja Grafindo.

[7] Kristiawan, M., \& Rahmat, N. (2018). Peningkatan Profesionalisme Guru Melalui Inovasi Pembelajaran [Improving Teacher Professionalism through Learning Innovations]. Jurnal Iqra': Kajian Ilmu Pendidikan, 3(2), 373 - 390. https://doi.org/10.25217/ji.v3i2.348

[8] Hendriyadi, Ritonga, A. H., \& Us, K. A. (2020). Management Leadership in Improving the Quality of Graduates of Private Islamic Religious Colleges in Jambi Province. International Journal of Progressive Sciences and Technologies (IJPSAT) Vol. 23 No. 2 November 2020, pp. 42-51 Retrieved from https://ijpsat.ijshtjournals.org/index.php/ijpsat/article/view/2308

[9] Budiyono, Lian, B., \& Fitria, H. (2020). The Influence of Principal Supervision and Organizational Climate toward Teacher's Performance. Electronic Research Journal of Social Sciences and Humanities Vol 2: Issue II, Apr - Jun 2020.

[10] Muttaqin, K., \& Rahmadoni, J. (2020). Analysis and Design of File Security System AES (Advanced Encryption Standard) Cryptography Based. Journal of Applied Engineering and Technological Science (JAETS), 1(2), 113-123. https://doi.org/10.37385/jaets.v1i2.78

[11] Miles, M. B., Huberman, A. M., \& Saldana, J. (2014). Qualitative Data Analysis, A Methods Sourcebook, Edition 3. USA: Sage Publications. 